\title{
Stele for Magistrate Jing Yun 景雲: An Eastern Han memorial stele from the south-west with reference to the Chuci 楚辭
}

\author{
Hajni Elias ${ }^{1}$ \\ University of Cambridge \\ hpe20@cam.ac.uk
}

\begin{abstract}
An Eastern Han stele with an unusual relief decoration and 367 character memorial inscription tells us much about the south-west of China in early imperial times. Unearthed in 2004 from the banks of the Yangtze River and dated to $173 \mathrm{CE}$, the stele was dedicated to Quren county magistrate Jing Yun who died 70 years earlier in $103 \mathrm{CE}$. The paper provides a full translation, annotation, and analysis of the stele's commemorative text, which borrows from the content and language of one of China's oldest anthologies of poems, the Chuci, and places it in its historical context. It also examines the iconography at the head of the stele which reflects beliefs in transcendence and the pursuit of immortality prevalent at the time and demonstrates its close relation to the inscription. Overall, the paper suggests that the decoration and text together exhibit a regional heritage that is distinct to the south-west, its memorial culture, and poetic and religious traditions. Keywords: Commemorative stele, Eastern Han dynasty, Chuci, Southwest China, Memorial culture
\end{abstract}

\section{Introduction}

In March 2004, archaeologists working prior to the flooding of the Three Gorges region on the Yangtze River in Jianmin village 建民村, Yunyang county 雲陽縣 in Chongqing Municipality, unearthed a stele dated to $173 \mathrm{CE}$ and dedicated to Quren county 朐忍縣 magistrate Jing Yun 景雲, who died 70 years earlier in 103 CE. Given the title "Stele for the Han dynasty Ba commandery Quren county magistrate Jing Yun” (漢巴郡朐忍令景雲碑) by scholars, it is now housed in the Chongqing China Three Gorges Museum (Figure 1). The stele's unusual relief carving and its inscription, which appears to borrow from one of the oldest anthologies of Chinese verse, the Chuci 楚辭, make it a fascinating artefact that tells us much about the south-west in early imperial times. It was discovered next to a rammed-earth

1 I presented a preliminary version of this study at the Needham Institute Text Reading Research Seminar on 11 October, 2019, in Cambridge. I wish to thank all participants at the seminar for their support and feedback. I am also grateful to the anonymous reviewer of $B S O A S$ who has provided invaluable comments and suggestions. In addition, my thanks, as always, go to Hugo Macey for his insight and patience, and to Abigail and Kazi for their support. Any remaining errors and mistakes are, of course, my own responsibility. 

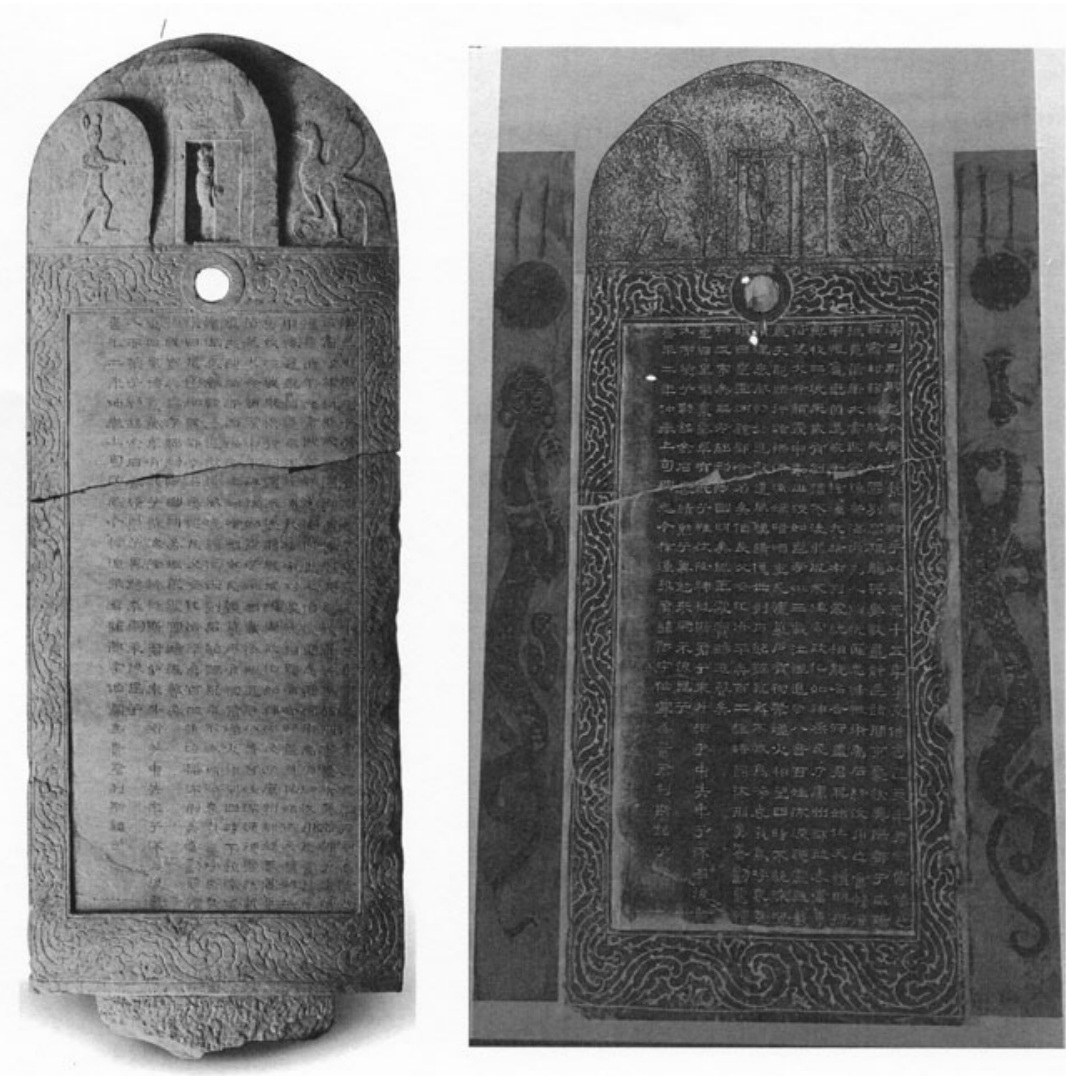

Figure 1. Stele for the Han dynasty Ba commandery Quren county Magistrate Jing Yun and its rubbing (Source: Photo by author)

building platform with four animal-shaped stone plinths partially preserved and contemporaneous with the stele itself. ${ }^{2}$ The archaeological report of the excavation site, known as the Jiuxianping platform 旧縣平臺, shows the remains of a fairly well preserved large architectural structure that possibly served as part of a protective building where the stele was placed for public view. The site also contains remains of a house foundation, channels for water drainage, and a wall, suggesting that it was an established building complex at the time ${ }^{3}$ (see Figures 2 and 3 ).

The stele is made of red sandstone and comprises a head, a body, and a stand, the latter heavily damaged and mostly missing. In its current state it is $220 \mathrm{~cm}$

2 See the archaeological report by the Jilin Provincial Institute of Cultural Relics and Archaeology and Yunyang Prefectural Office of the Preservation of Cultural Relics 吉林省文物考古研究所與雲陽縣文物管理所, “Chongqing Yunyang jiuxian ping taiji jianzhu fajue jianbao”重慶雲陽旧縣坪台基建築發掘簡報, Wenwu 2008.1, 22-31.

3 See Jilin Provincial Institute of Cultural Relics and Archaeology and Yunyang Prefectural Office of the Preservation of Cultural Relics, "Chongqing Yunyang jiuxian ping taiji jianzhu fajue jianbao", 23-24; and Kenneth Brashier, Public Memory in Early China (Cambridge and London: Harvard University Press, 2014), 467. 


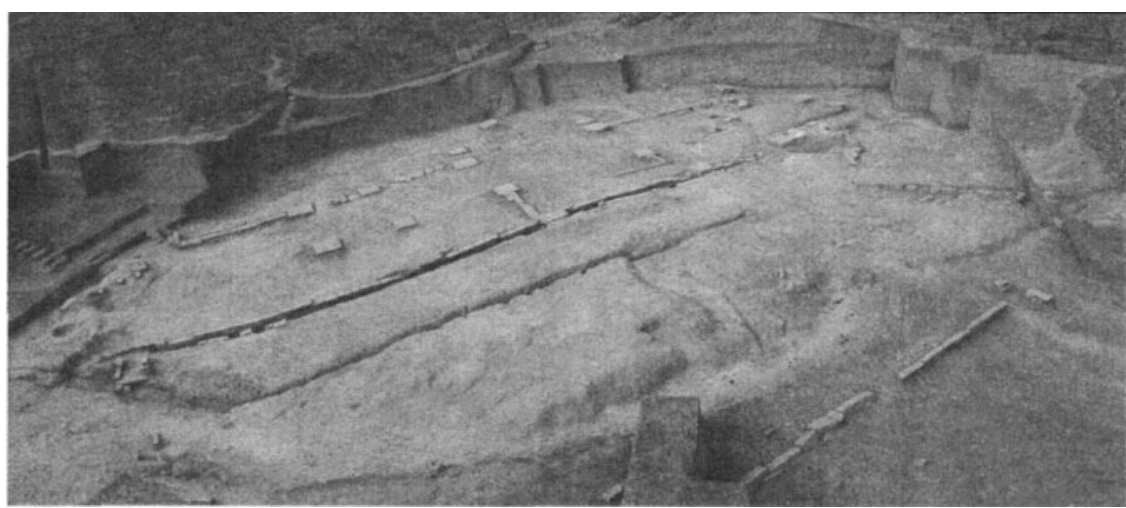

Figure 2. Excavation site at Yunyang county, Chongqing municipality (Source: Jilin Provincial Institute of Cultural Relics and Archaeology and Yunyang Prefectural Office of the Preservation of Cultural Relics, "Chongqing Yunyang jiuxian ping taiji jianzhu fajue jianbao", 23)

high and $137.5 \mathrm{~cm}$ wide. It contains an inscription of 13 lines with a total of 367 characters carved on the obverse of the stele. The head of the stele bears a complex decoration in high relief carving which is singular in content and a rare instance on monuments of this type. The reverse of the stele, where we would expect to find the names of those who had commissioned and financed the making of the stele, is left plain and undecorated. Thus, apart from the commemorative text, Jing Yun's stele does not contain a donors' list.

Eastern Han dynasty stelae are generally carved with a decorative border that envelopes the main calligraphic inscription which may extend to both sides of the monument. In some cases the head of the stele bears a simple carved image, such as the bird seen on the stele erected for the "filial and incorrupt" (xiaolian 孝廉) official Liu Min 柳每 (fl. 146 CE), or a dragon coiled around the title carved on the head of the stele made for Ba commandery 巴郡 governor Fan Min 焚敏 dated to $205 \mathrm{CE} .{ }^{4}$ Complex decorations, such as those seen on Jing Yun's stele, remain exceptionally rare. Overall, the stele is impressive for its size, its deeply carved composite decoration, and for its calligraphy that is skilfully executed in the clerical script.

The location where Jing Yun's stele was discovered is noteworthy. Yunyang county was the ancient site of Quren county, which is recorded in the Hanshu as one of the 11 counties belonging to Ba commandery. ${ }^{5}$ The Huayang guo zhi 華陽國志 (Records of the Kingdoms South of Mount Hua) compiled by Chang $\mathrm{Qu}$ 常璩 (c. 291-361 CE), mentions Quren being famous for its ale, Lingshou trees 靈壽木, oranges, salt wells, and numinous turtles (ling gui 靈龜). The wells of the local Tang Spring 湯溪 are said to have produced salt rocks as large as one square cun. ${ }^{6}$ The county is also listed in the Shuijing zhu 水經註

4 Sichuan lidai beike 四川歷代碑刻, ed. Gao Wen 高文 and Gao Chenggang 高成剛 (Chengdu: Sichuan University Press, 1990), pls 50 and 51.

5 Hanshu 漢書 (Beijing: Zhonghua, 1962), 28A.1603.

6 Ren Naiqiang 任乃強, Huayang guo zhi jiaobu tuzhu 華陽國志校補圖注 (Shanghai: Guji chubanshe, 1987), 1.36. One cun in the Eastern Han period is approximately $2.3 \mathrm{~cm}$ in today's measurement. 
(a)

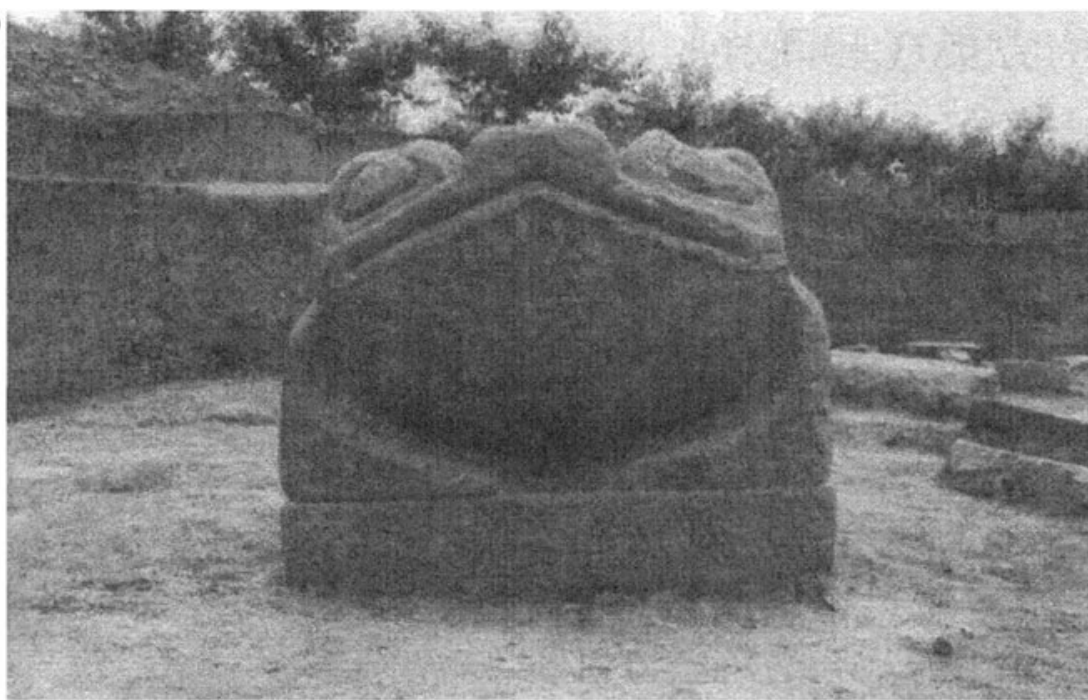

(b)

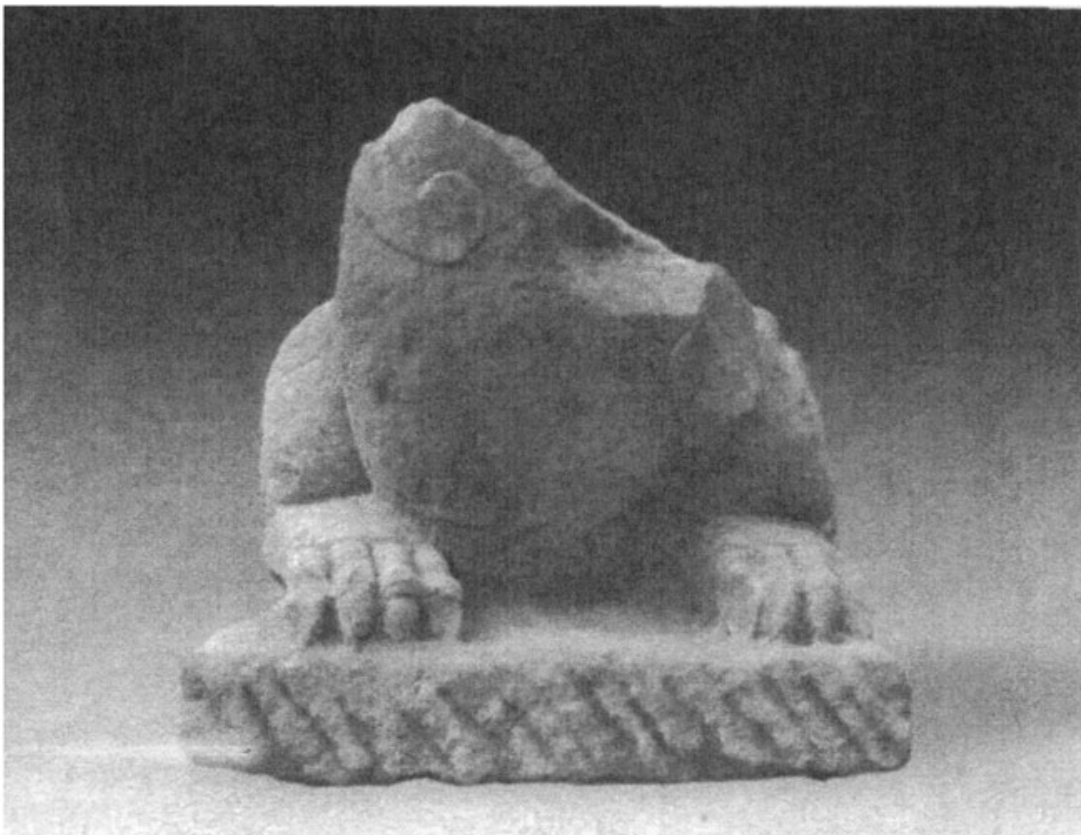

Figure 3. Remains of animal-shaped stone plinths from the excavation site at Yunyang county, Chongqing Municipality (Source: Jilin Provincial Institute of Cultural Relics and Archaeology and Yunyang Prefectural Office of the Preservation of Cultural Relics, "Chongqing Yunyang jiuxian ping taiji jianzhu fajue jianbao", 25)

(Commentary on the Classic of Waterways), compiled by Li Daoyuan 李道原 (d. $527 \mathrm{CE}$ ), which records the establishment of the earliest official Salt Bureau (yanguan 鹽官) in Ba commandery, in 118 BCE. This bureau administered over 
100 salt wells in the region. ${ }^{7}$ From these sources we know that Quren was a county of considerable wealth and abundant natural resources which made it one of the most prosperous territories in the south-west.

Stelae form an integral part of the physical make-up of the south-west's landscape. The etymological dictionary, the Shiming 釋名, compiled by Liu Xi 劉熙 (d. c. $219 \mathrm{CE}$ ), advises how stelae emerged as a primary symbolic form with a funerary or commemorative function from the early Eastern Han period. ${ }^{8}$ They served as locators, but more importantly, they were monuments made for public scrutiny and were thus placed in strategic positions where they were visible for all to see. ${ }^{9}$

Eastern Han stelae may be divided into two categories: those that were made for funerary purposes to honour the deceased and the family's ancestry are known as mubei 墓碑, mortuary or ancestral stelae. This type of stele connected chamber tombs built underground with monuments erected above ground. Wu Hung describes how a Han burial site was marked by a tumulus above the tomb. The beginning of the spirit path (shendao 神道) that led to the tumulus was first made visible by a pair of gate towers (que 䦕). Visitors or family members of the deceased would embark on the spirit path that guided them through the gate towers, after which they encountered a number of stone sculptures in the form of guardian animals and figures. Following the path, they were further directed to one or two stelae erected in front of an ancestral shrine (zongmiao 宗廟), with the tumulus behind it. ${ }^{10}$ The tomb, where sacrifices were offered, functioned primarily to serve the family; however, mubei were intended as public statements erected for everyone to see. Made of stone and incised with calligraphy, they customarily documented information on the deceased's ancestry and lineage, his or her achievements, and perhaps most importantly, stated why the person merited remembrance. Information on the stele was often repeated on the que that accompanied it, and at times inside the tomb as well. In summary, the function of the mubei confirms that the burial complex during the Eastern Han period was a shared space belonging to both private and public domains. Designed to benefit the dead as well as the living, mubei represented a synthesis of funerary and social memorial.

The second group of stelae were made for the general public to commemorate a person's meritorious deeds and to uphold a model citizen for society and later generations to follow. These are known as jishi bei 紀事碑, songde bei 頌德碑 or commemorative stelae. ${ }^{11}$ The majority of extant commemorative stelae were erected for men, although a very small number were also made to honour

7 Shuijing zhu shu 水經注疏, ed. Yang Shoujing 楊守敬 and Xiong Huizhen 熊會貞 (Nanjing: Jiangsu guji chubanshe, 1989), 33.2801.

8 The Shiming, compiled at the end of the Eastern Han dynasty by Kong Xi 孔熙, is an etymological dictionary written with the Confucian concept of rectifying names and terms and providing the correct designation of all things. See Michael Loewe, Early Chinese Texts: A Bibliographical Guide (Berkeley: University of California Press, 1993), 424-8.

9 Shiming 釋名, 6.5 (“Shidian yi” 釋典藝), in Gujin yishi 古今逸史, fasc. 3 (Shanghai: Shangwu chubanshe, 1937).

10 Wu Hung, Monumentality in Early Chinese Art and Architecture (Stanford: Stanford University Press, 1995), 189-250.

11 Luo Zhiping 羅志平, Yemen de tiankong 爺們的天空 (Beijing: Xiuwei zixun, 2016), 40, where the terms jishi bei and songde bei are explained. 
women. Commemorative stelae were generally commissioned and financed by local officials or friends, colleagues and subordinates of the dedicatee, indicated by a list of donors' names that was usually placed on the reverse of the stelae. They were erected in a public space that was often linked to the person's meritorious services.

There is some debate among Chinese scholars over the nature of Jing Yun's stele. Cheng Diyu argues that the language of the inscription, which contains an extensive expression of mourning, is of a funerary nature and that the stele is therefore a mubei. However, the stele was not discovered at a cemetery site nor was it commissioned by any of the Jing family members. It was made on the orders of the Quren magistrate Yong Zhi 雍陟 to commemorate Jing Yun for his meritorious services to the county. ${ }^{12}$ As the stele only mentions Yong Zhi's name as dedicator, it is likely that it was primarily commissioned and financed by him. Kenneth Brashier confirms the stele's commemorative nature and suggests that it was intended to pay homage to someone who had become a local deity-like figure in people's memories. Although the stele offers one of the longest and most evocative images of public remembrance for a local prefect, nevertheless, it was made as an outdoor monument for public consumption and not a carefully preserved text kept within the household. ${ }^{13}$

Since its discovery, Jing Yun's stele has been studied by a number of Chinese and Japanese scholars who have provided annotations of its inscription, but have not analysed the nature and structure of its language, nor sought to explain the iconography of the carved decoration and its relevance to the text below it. ${ }^{14}$ Brashier mentions the stele in both of his works, Ancestral Memory in Early China and Public Memory in Early China, observing how the text typically borrowed lines and formats from earlier classical literature with the aim of

12 Rafe de Crespigny, A Biographical Dictionary of Later Han to the Three Kingdoms (23-220 AD) (Leiden: Brill, 2007), 989, records Yong Zhi being from Hanzhong and the eldest son of Yong Wang 雍望. He was nominated xiaolian (Filial and Incorrupt), became Quren county magistrate in Ba commandery and was subsequently promoted to the governorship of Yizhou commandery. In $176 \mathrm{CE}$ he was taken prisoner during a rebellion by non-Han ethnic tribes and was subsequently rescued by $\mathrm{Li}$ Yong 李顒, new governor of Yizhou, who with the help of the Bandun people put down the rebellion. Hou Hanshu 後漢書 (Beijing: Zhonghua, 1965), 8.337, 86.2843, 2847; Huayang guo zhi, 1.24 and 4.237 .

13 See Brashier, Public Memory in Early China, 1-4; and Kenneth Brashier, Ancestral Memory in Early China (Cambridge, MA: Harvard University Press, 2011), 94-5.

14 See Cheng Diyu 程地于, “Han Bajun Quren ling Jing Yun bei kaoshi” 漢巴郡朐忍令景 雲碑考釋, Sanxia Daoxue xuebao, 2006.5, 5-15; Li Qiao 李喬, “Cong 'Jing Yun bei' kan Jing shi qiyuan ji Handai yiqian de qianxi” 從 ‘景雲碑’ 看景氏起源及漢代以前的 遷徙, Zhongyuan wenwu, 2009.4, 55-61; Ren Guiyuan 任桂園, “Han Bajun Quren gucheng yizhi yu ‘Jing yun bei”” 漢巴郡朐忍故城遺址與 “景雲碑”, Yenye shi yanjiu, 2015.1, 64-71; Yuan Yansheng 袁延胜, “Xin chu 'Han Jing Yun bei' ji xiangguan wenti” 新出 “漢景雲碑” 及相關問題, Zhongyuan wenwu, 2007.3，58-63; Wei Qipeng 魏启鵬, “Du Sanxia xin chute Dong Han Jing yun bei” 讀三峽新出土東漢景 雲碑, Sichuan wenwu, 2006.2, 64-7; He Xilin 賀西林, “Handai yishuzhong de yuren ji qi xiangzheng yiyi” 漢代藝術中的羽人及其象征意義, 2010.7, 46-55; Wang Lei 王否, “Dong Han Jing Yun bei de tuxiang xingshi yu shijue guannian” 東漢景雲碑 的圖像形式與視覺觀念, Rongbaozhai, 2015.1, 166-73; and Iizuka, “Kan Guninrei Keigun ishibumi" shotakubun ni miru Kei'un to sono shūhen”, 4. 
celebrating Jing Yun's achievements. ${ }^{15} \mathrm{He}$ recognizes the stele's importance in early China's commemorative culture but notes how little detail is supplied and suggests that the text is restricted by a Confucian rhetoric that merely serves to foster and preserve public memory. ${ }^{16}$

Following an examination of the iconography of the decoration on the head of the stele, this paper provides a full translation, annotation, and analysis of the inscription and for the first time establishes the link between the complex message conveyed in the decoration and the text. Second, it places the stele in its historical context and considers the possible reasons behind its commissioning 70 years after Jing Yun's death. Another aspect examined is the language and literary style of the stele's eulogy which appears to have borrowed from the poetic tradition of the Chuci. Central themes of lament and some of the more eclectic concepts of the sacred expressed in the songs and poems of the Chuci are evident in the text of the stele. The paper argues that the stele shows how people in the south-west were not only familiar with the poems of the Chuci, but valued it as a text closely linked to their cultural heritage. ${ }^{17}$

\section{Relief decoration on Jing Yun's stele}

The head of the stele is carved in relief with three images in separately defined arches which may represent mountains, associated with the notion of the sacred mountain in Eastern Han tomb art, or are simply of a decorative form (Figure 4). ${ }^{18}$

On the left we see a tall figure with a pair of ears pointing upwards from the crown of its head, suggesting that we are looking at a celestial immortal being, generally referred to as xian 仙, but also known as the feathered or winged people (yuren 羽人), the latter named for the feathers often depicted on their backs. ${ }^{19}$ The xian on the stele displays all the characteristics of Han-period

15 Brashier, Ancestral Memory in Early China, 95; and Brashier, Public Memory in Early China, 1-4, 57, 167, 317-8, 321, 366-7.

16 Brashier, Public Memory in Early China, 1-2.

17 The Chuci is a compendium of poetic songs from the southern state of Chu collected in the second century CE by Wang Yi 王逸 $(\mathrm{d} .158 \mathrm{CE})$ in the Chuci zhangju 楚辭章句. For the two major translations of the Chuci in English see Gopal Sukhu, The Songs of Chu (New York: Columbia University Press, 2017), and David Hawkes, The Songs of the South: An Ancient Chinese Anthology of Poems by Qu Yuan and Other Poets (Harmondsworth: Penguin Press, 1985).

18 See a stele given the title by scholars "Stele for Kong Qian (Kong Qian bei 孔謙碑)", dated to $154 \mathrm{CE}$ and discovered in Shandong province. The carved decoration on the head of the stele depicts three arched forms related to that seen on Jing Yun's stele. The Kong Qian stele is examined by Miranda Brown in "Han steles: how to elicit what they have to tell us", in Cary Y. Liu (ed.), Re-envisioning Culture: Ideals, Practices, and Problems of the "Han Dynasty Wu Family Shrines" (Princeton: Princeton University Press, 2008), 182-3.

19 See He Xilin, "The feathered being and its symbolic meaning in Han dynasty art", Chinese Archaeology 11, 2011, 165-75. The yuren are mentioned in "Wandering far away" of the Chuci in connection with the land of immortality as follows, "I went to the plumed men on Cinnabar Hill; I loitered in the ancient land of No-death" (仍羽人 於丹丘, 留不死之舊鄉). See Hong Xingzu 洪興祖 (1090-1155), Chuci buzhu 楚辭 補注 (Beijing: Zhonghua shuju, 1983), 5.276. See also Zornica Kirkova, Roaming 


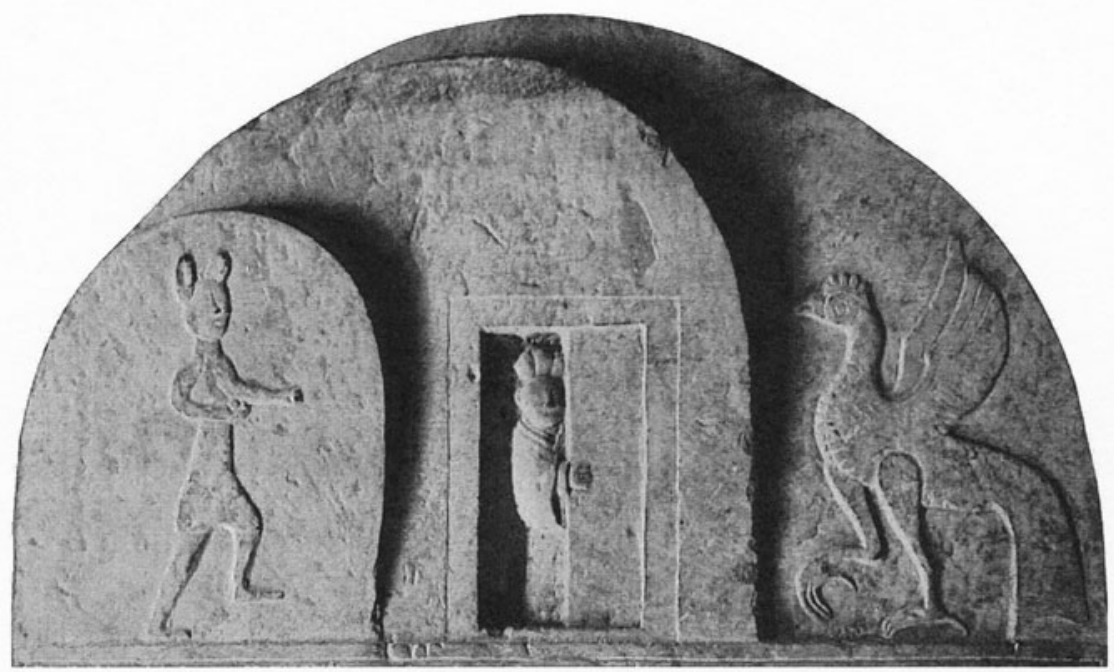

Figure 4. Detail of the head of the "Stele for the Han dynasty Ba commandery Quren county magistrate Jing Yun" (Photo by author)

depictions of an immortal, with striking ears and foreign-like facial features such as a prominent nose that distinguishes it from ordinary humans. He Xilin suggests that its portrayal could have originated from the Chu culture, influenced by the practices of prolonging life that were gradually becoming popular in Chu society during the middle and late Warring-States period. ${ }^{20}$ The connection between the xian and Chu is significant and shall be explored later in the paper.

The xian on Jing Yun's stele is shown with arms stretched in a gesture of offering. In its right hand it is holding a small round object that appears to be the pill of immortality (Figure 5). The figure has been also identified as the “Jade Rabbit" (Yutu 玉兔), possibly because of its large rabbit-like ears and this mythical creature's association with making the elixir of immortality. However, in the tomb art of the south-west the Yutu is customarily depicted in the company of Xiwangmu 西王母, in the form of a rabbit squatting on its haunches, holding a pestle and mortar as it pounds the drug of immortality, and not as a standing human figure. ${ }^{21}$

into the Beyond: Representations of Xian Immortality in Early Medieval Chinese Verse (Leiden: Brill, 2016), 94; and Leslie Wallace, "Betwixt and between", Ars Orientalis 41, 2001, 73-101, where the xian are described as feathered sprite-like or dragon or snaketailed figures with a close connection to the animal world, demonstrating that there was not a single source or iconographic unity for the depiction of the xian in early tomb art.

$20 \mathrm{He}$, "The feathered being and its symbolic meaning in Han dynasty art", 166.

21 See Iizuka, "Kan Guninrei Keigun ishibumi' shotakubun ni miru Kei'un to sono shūhen", 2, Wei, "Du Sanxia xin chute Dong Han Jing yun bei", 64 and Ren, "Han 


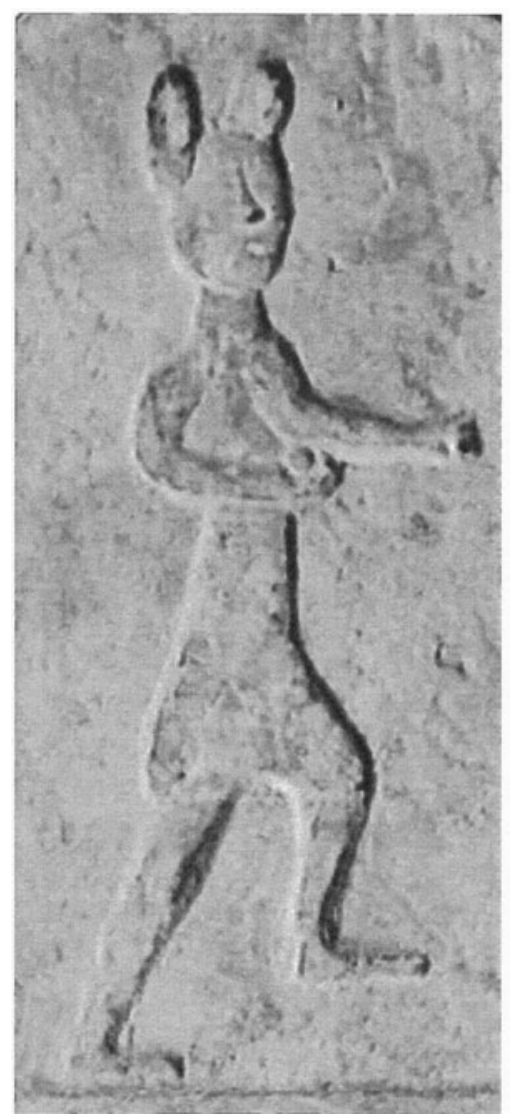

Figure 5. Details of carving on the head of stele (Photo by author)

A similar xian to that on the stele is described in the Han poem, preserved in the Yuefu shiji 樂府詩集, titled “Song of a Long Journey” (Changge xing 長歌行):

仙人騎白鹿, 發短耳何長. 導我上太華, 攬芝獲赤幢. 来到主人門, 奉藥一玉箱. 主人服此藥, 身體日康强, 發白復更黑, 延年壽命長.

The immortal is mounted on a white deer. Oh how short is his hair! How long are his ears! He shall lead us to the Supreme Floral Heaven, in order

Bajun Quren gucheng yizhi yu 'Jing yun bei', 70, where the xian is identified as the Jade Rabbit. For an explanation of the Jade Rabbit and its association with Xiwangmu see Jean M. James, "An iconographic study of Xiwangmu during the Han dynasty", Artibus Asiae, 55, 1995, 17-41. Xiwangmu, considered a local deity, features prominently in the art of the south-west, especially with her sacred companions, the nine-tailed fox, the three-legged crow, the toad and the rabbit. 
for us to grasp the lingzhi and receive the red banner. ${ }^{22} \mathrm{He}$ shall come to the gate of the master, bringing drugs in a jade casket. If the master ingests this drug, his body shall grow healthier and stronger every day. His white hair shall once more turn black, and he shall prolong his years and gain longevity. ${ }^{23}$

This image of a xian is also closely related to that found on a stone sarcophagus from a cliff tomb at Zhangjiagou 張家沟 in Hejiang county, Sichuan province, where an immortal (also with large ears) is shown holding a round pill in a similar gesture of offering to Xiwangmu seated on her dragon and tiger throne. Scholars have given the pictorial scene on the sarcophagus the title "Picture of [Hou] Yi Seeking the Medicine [of Immortality]” (Yi qiu yao tu 羿求藥圖), with the immortal identified as the mythical archer Hou Yi 后羿, who was gifted the pill of immortality ${ }^{24}$ (Figure 6).

In early legends Hou Yi was not given the pill by Xiwangmu but by the Gods, nor is he depicted as a xian but as a human archer on contemporaneous tomb art from the Central Plains of China. ${ }^{25}$ Given this, notwithstanding the identification of the figure on the sarcophagus as the archer Hou Yi, we may simply be looking at a xian rather than the mythological figure of Hou Yi specifically. The xian images on the stele and on the sarcophagus from Hejiang are characteristic of the south-west, where stories and characters were adapted to suit local culture and decorative traditions.

Regarding the role of these immortals, He Xilin notes how both visual and textual evidence show them serving as the aid or guide to transcendence and also as bestowing the drug of immortality. ${ }^{26}$ Robert Campany describes xian as the individual who sought to become a transcendent, a god-like being with supernormal powers. This quest for transcendence became a major form of religious expression by the late Eastern Han period and helped lay the foundation for the growth of the Way of the Celestial Masters (Tianshi dao 天師道), the first Daoist movement founded by Zhang Daoling which established itself in the south-west. Campany, in his examination of the role of the xian, argues that the quest to become xian-like or a holy person in society became a social phenomenon, and practitioners were not isolated xian-hood seekers but gained

22 Lingzhi refers to the Ganoderma lucidum, an oriental fungus believed to promote health and longevity. The "red banner" (chichuang 赤幢) refers to the ceremonial banner held by officials.

23 Guo Maoqian 郭茂倩 (1041-1099), Yuefu shiji 樂府詩集 (Beijing: Zhonghua shuju, 1979), 30.364.

24 On Hou Yi see Mori Masako, "Restoring the epic of Hou Yi", Asian Folklore Studies $54 / 2,1995,239-57$.

25 See depictions of Hou Yi on the relief carvings from the former site of the $\mathrm{Wu}$ family shrines (Wu Liang ci 武梁祠) in Jiaxiang county 嘉祥縣, Shandong province, where he is shown as a human archer. See Wu Hung, The Wu Liang Shrine: The Ideology of Early Chinese Pictorial Art (Stanford: Stanford University Press, 1989), 41, 57.

$26 \mathrm{He}$, "The feathered being and its symbolic meaning in Han dynasty art", 173. 


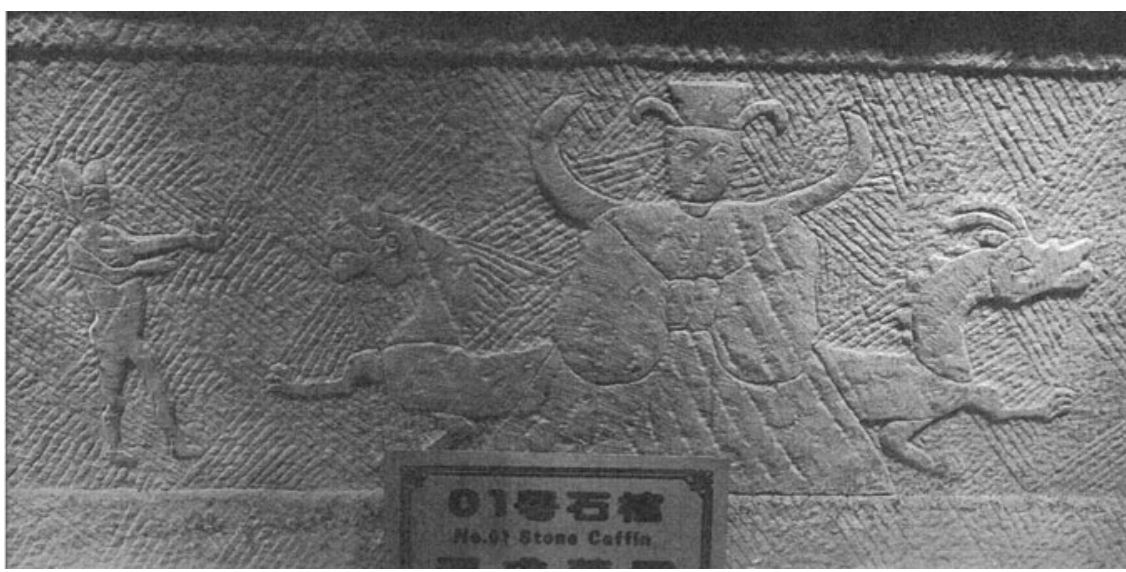

Figure 6. Section of stone sarcophagi with "Picture of Hou Yi seeking the medicine of immortality" (Photo by author)

considerable reputations as holy people. ${ }^{27} \mathrm{We}$ shall return later in the paper to the notion of Jing Yun's representation as a god-like figure in the text of the stele.

In tomb art xian are usually depicted in the company of other creatures, such as dragons, tigers, deer, and birds - propitious animals associated with its supernatural powers. ${ }^{28}$ Such is the function of the Vermilion Bird (zhuque 朱雀) carved on the right arch of the head of the stele. The Vermilion Bird presides over the southern quadrant and symbolizes the yang principle of brightness, light, and heat. ${ }^{29}$ It is also linked to the Daoist alchemical and physiological practices as referenced by Wang Yi 王逸 (fl. 114-119 CE) in his commentary to "Wandering far away" (Yuanyou 遠游) ("Yuanyou" hereafter) in the Chuci. The poem reads, "I pointed to the God of Fire and we galloped straight toward him. I was on my way to the Southern Doubts. Seeing the vastness of the world beyond my homeland, I let myself float as though on open seas" (指炎神 而直馳兮，吾將往乎南疑. 覽方外之荒忽兮, 沛目象而自浮). ${ }^{30}$ In his commentary, Wang Yi notes on these lines that the "God of Fire" is the quintessence of the "True Mercury" of the Vermilion Bird of the southern region. Thus, he treats this passage as a virtual manual of alchemical technique with its references to the particulars of the elixir of immortality. ${ }^{31}$ The "Yuanyou" had much in common with the Daoist cult of the immortals and is labelled as the earliest

27 Robert Ford Campany, Making Transcendents. Ascetics and Social Memory in Early Medieval China (Honolulu: Hawaii University Press, 2016), 151-3.

28 Pictorial carvings of xian in the company of other animals are included in Gao Wen 高文, Zhongguo huaxiang shiguan quanji 中國畫像石棺全集 (Taiyuan: Sanjin chubanshe, 2011), 129, 135, 165, 166, 205.

29 The Vermilion Bird is not to be mistaken for the phoenix or fenghuang 鳳凰, also frequently depicted in Han tomb art.

30 Chuci buzhu, 5.284; tr. Sukhu, The Songs of Chu, 148. See also Paul Kroll, "On 'Far Roaming"', Journal of the American Oriental Society 116/4, 1996, 658.

31 Chuci buzhu, 5.284. 
youxian 遊仙 (wandering immortals or wandering amongst immortals) genre of poems which depict journeys into the realm of the immortals. ${ }^{32}$

The Vermilion Bird features regularly on decorated stone sarcophagi from the south-west, frequently depicted in the company of the physician Bian Que 扁鵲 (c. 401-310 BCE). ${ }^{33}$ For example, Bian Que, in the form of a xian (with a human body and large pointed ears) is shown receiving the medicine herb from the Vermilion Bird on a stone sarcophagus unearthed from a cliff tomb at Hejiang county. ${ }^{34}$ The portrayal of Bian Que, the Vermilion Bird, and the medicine plant on the sarcophagus represents an equivalent iconography to that on Jing Yun's stele where the plant was substituted by the pill of immortality (Figure 7).

The central arch on the stele is rendered with the image of a half-open door with a figure standing on the threshold peeking out between the two door-leaves. This image is primarily found in a funerary context in Han art and is explained by scholars as representing an entrance to another, invisible space. ${ }^{35}$ The door is always half open with the other half firmly shut, at times with a figure shown peeking out, but may also be found merely as a half-open door with no-one behind it. It is an image that is highly suggestive yet at the same time enigmatic. It invites speculation about the role of the mysterious person, what the image symbolizes, and where the half-open door was thought to lead. Fei Deng suggests that the scene is about the possibility of entering the realm where celestial beings existed, and that the door can be seen as a means of access into that otherworld. ${ }^{36}$ Just as with the Vermilion Bird, a passage from the "Yuanyou" may be relevant to our understanding of the half-open door image. In the poem the author wishes to follow the famous Daoist immortal, Wang Qiao 王喬 saying, "Drifting on a mild southern breeze, I arrive at South Nest to spend the night. Where Master Wang with open doors receives me. And I sought from him the secret of primordial energy” (順凱風以從游兮, 至南巢而壹息. 見王子而 宿之兮, 審壹氣之和德). ${ }^{37}$ The poet laments his wasted years and his incapacity to play a role in government and decides to move on and to take Wang, a successful transcendent, as his model. Devoting himself to various esoteric practices, he is finally able to visit Wang's spiritual domain in the south and receive instructions on nurturing the vital breath from the legendary master himself. ${ }^{38}$ The description of Master Wang receiving the poet into his mythical

32 Sukhu, The Songs of Chu, 142.

33 The sarcophagi were examined by this author during a field trip conducted at the museum. The decoration on the sarcophagi has been given the title of "Bian Que Picking Medicinal Herbs” (扁鵲採藥圖) by scholars at the museum.

34 This information was obtained from a personal interview with the Hejiang County Han Dynasty Pictorial Stone Sarcophagi Museum (Hejiangxian Handai Huaxiang Shiguan Bowuguan 合江縣漢代畫像石棺博物館) director, Zhang Caixiu 張采秀, during a field trip visit to the museum.

35 See Fei Deng, "Realms beyond: half-open doors in Chinese funerary art", Religion and the Arts 20, 2016; Paul Goldin, "The motif of the woman in the doorway and related imagery in traditional Chinese funerary art", Journal of the American Oriental Society 121/4, 2001, 539-48; and Wu Hung, Monumentality in Early Chinese Art and Architecture (Stanford: Stanford University Press, 1995), 259, 246.

36 Fei, "Realms beyond: half-open doors in Chinese funerary art", 86.

37 Chuci buzhu, 5.275; tr Sukhu, The Songs of Chu, 145.

38 Kroll, "On 'Far Roaming'”, 656. 


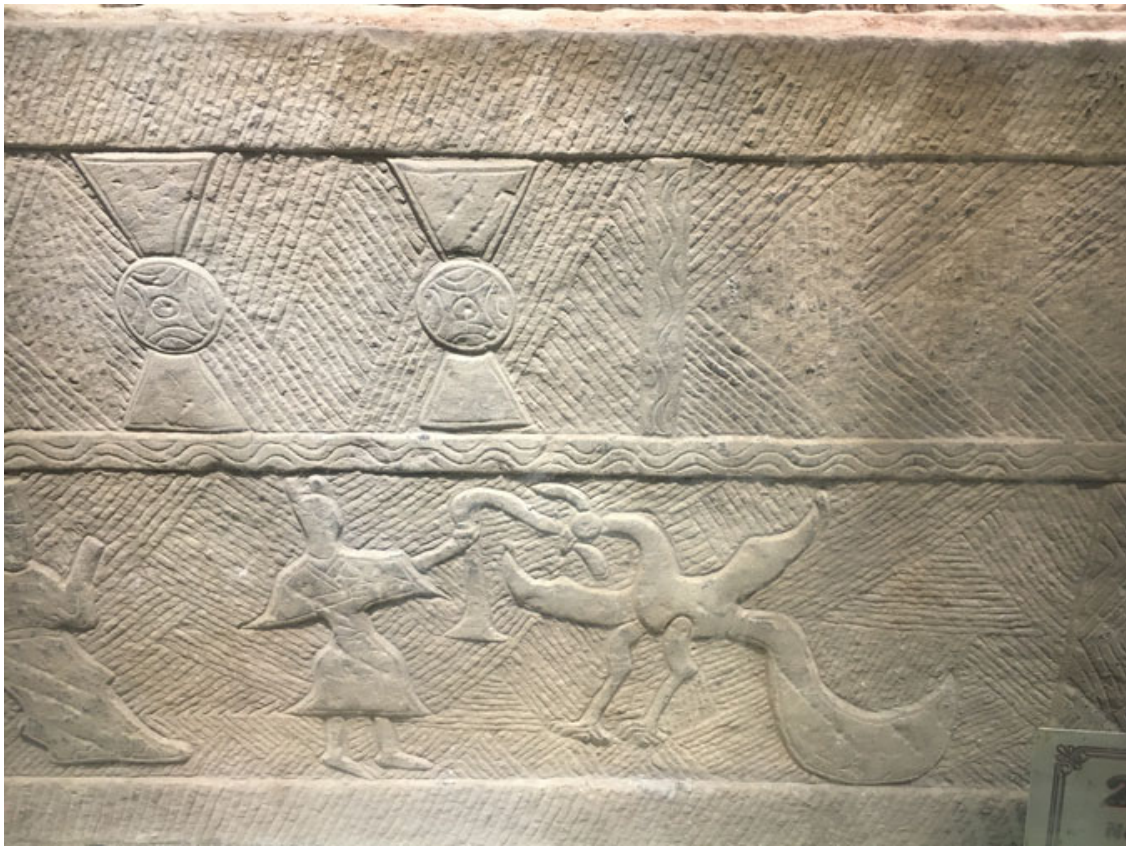

Figure 7. Section from a stone sarcophagus with "Picture of Bian Que and the Vermilion Bird" (Photo by author)

world so that he can become a free spiritual being in the "Yuanyou" seems very like the image of the half-open door with the figure behind it on the stele. The image may even be, given the other links between the stele and the "Yuanyou" explored later in the paper, a reference to this passage from the poem itself.

The two sides of the stele are carved with the images of the Azure Dragon (Qinglong 青龍), the guardian of the East with the Sun above its head on the left, and the White Tiger (Baihu 白虎), the guardian of the West with the Moon above its head on the right. The two beasts respectively represent the yang and yin opposition and interaction. In tomb art they are generally symbols of protection, placed near the tomb entrance to guard against ghosts and evil spirits. Together they communicate the wish to ward off evil. A further relevant meaning to the stele is the symbolism represented by the joining of the dragon and tiger suggested by the phrase "the way of not dying" (不死之道). This phrase is explained in the Hanfeizi 韓非子 where we read about the King of Yan 燕王 and his passionate pursuit of immortality. ${ }^{39}$

In summary, the iconography of the carved decoration on the head and sides of the stele may be explained as the imagined sequence of journey or transcendence into a paradisiacal sphere, located behind the half-open door, aided by the propitious forces of the xian, the Vermilion Bird, and the pill of immortality. Help is also obtained from the combined forces of the tiger and dragon. The

39 Han Feizi jiaoshi 韓非子校釋 (Taibei: Taiwan shangwu yinshuguan, 1969), 5.538 (“Wai chushuo" 外儲說). 
ability to embark on a distant journey for the transformation of one's state of being was thought possible through the consumption of elixirs that became the main objectives of the theme of "distant journeys" reflected in the poems and songs of the Chuci. ${ }^{40}$ We read in the "Yuanyou" how the poet "followed the Winged People to the Cinnabar Hills, and stayed in the old country of the Undying” (仍羽人於丹丘兮, 留不死之舊鄉), with the Winged People portrayed by the xian and the Cinnabar Hill, their abode, located behind the halfopen door on the stele. ${ }^{41}$

Although the various decorative elements found on the head of Jing Yun's stele are not unique to the south-west and, as is the case with the iconography of the half-open door which was readily employed in the tomb art of north China, there is nevertheless a connection between the images of the xian, the half-open door, and the Vermilion Bird and the Chuci, in particular the poem "Yuanyou". ${ }^{42}$ While the themes of a journey and that of immortality are reflected in the pictorial carving, we find references to sorrow and lament ideas that are pivotal to the songs and poems of the Chuci- expressed in the inscription of the stele which will be explored following the translation of its text below.

\section{Translation of the inscription on Jing Yun's stele}

漢巴郡朐忍令廣漢 景雲叔于

以永元十五年季夏 仲旬已亥卒.

君帝高陽之苗裔,

封兹 45 楚熊,

氏以國别.
In the Han, Ba commandery Quren county magistrate Jing, from Guanghan, and whose now tabooed personal name was Yun and his courtesy name was Shuyu, passed away on the jihai day, in the middle of the sixth month of the 15th year of the Yongyuan reign. ${ }^{43}$

The gentleman was a descendant of Gaoyang, the God Lord, ${ }^{44}$

[and his lineage was] bestowed [with the feudal title and appanage] by Xiong [Yi] from Chu. ${ }^{46}$

The clan thus became distinguished in the state [of Chu]. ${ }^{47}$

40 Kirkova, Roaming into the Beyond, 241.

41 Chuci buzhu, 5. 276; tr. Sukhu, The Songs of Chu, 145 and footnotes 11-12.

42 For a detailed study on the iconography of the half-open door see Fei Deng, "Realms beyond. half-open doors in Chinese funerary art", Religion and the Arts, vol. 20, 59-91, where the author mentions early examples found in tombs from Luoyang and Yishui in Shandong province.

43 Dated to $103 \mathrm{CE}$.

44 Here I have followed Gopal Sukhu's translation which is after the "Lisao" in Chuci buzhu, 1.12 (帝高陽之苗裔). See Gopal Sukhu, The Shaman and the Heresiarch (Albany: State University of New York Press, 2012), 183.

$45 C i$ 兹 is a graphic variant and archaic use of $c i$ 此.

46 Xiong Yi 熊繹 (r. 11th c. BCE) was the first viscount and ruler of the state of Chu.

47 Hanshu, 1B.66, mentions the Jing clan as one of the five great clans from the states of Qi 齊 and Chu 楚 who were transferred to the Guangzhong region during the reign of Gaozu 高祖 (r. 202-195 BCE). 
高祖龍興,

婁敬畫計,

遷諸關東豪族英傑，

都于咸陽,

攘竟 52 蕃衛.

大業既定，

鎮安海内.

先人伯流,

罒 55 志慷慨.

術 57 禹石纽,
When Gaozu arose like a dragon, ${ }^{48}$

Lou Jing ${ }^{49}$ drew up plans

to transfer the various brave and prominent magnate

clans from the east of the pass, ${ }^{50}$

set up the capital at Xianyang, ${ }^{51}$

repelled [the Xiongnu at] the borders and safeguarded

and defended [the empire]. ${ }^{53}$

As soon as [Gaozu's] great enterprise was established, control and stability [were restored] within the seas.

The forefather Boyan, ${ }^{54}$

was one with aspirations and high martial spirit. ${ }^{56}$

$\mathrm{He}$ explained how $\mathrm{Yu}$ [was born at] Shiniu, ${ }^{58}$

48 Huang Hui 黃暉 and Liu Pansui 劉盼遂, Lunheng jiaoshi 論衡校釋 (Beijing: Zhonghua shuju, 1990), 71.1374 (“Bushi”筮), mentions Gaozu rising as a dragon (高祖龍興), a reference to the tale of a dragon seen hovering over Gaozu's mother who soon after became pregnant with him. Shiji 史記 (Beijing: Zhonghua, 1959), 8.343, records how when Gaozu got drunk and lay down to sleep people would always see something like a dragon over the place where he was sleeping (見其上常有龍). He is also described as having a high nose, complete with whiskers and a striking beard. People would observe that his distinct features had some resemblance to those of a dragon.

49 Lou Jing 婁敬, advisor to Emperor Gaozu, first suggested that it would be advantages to set up the capital in Xianyang 咸陽. He also advised the emperor to send a princess to the Xiongnu 匈奴 chief instead of engaging in endless fighting against the steppe hordes, thus initiating the peace-by-marriage policy (heqin 和親). Lou Jing was also concerned with the danger from the side of the descendants of the former regional rulers of the Zhou period (11th c. BCE-221 BCE). In order to deprive them of their local power, he suggested they should be settled in the metropolitan region of Guangzhong. See Shiji, 99.2715-28; tr. Burton Watson, Records of the Grand Historian. Han Dynasty. Vols I-II (New York: Columbia University Press, 1993), I.239-40, where it is mentioned how members of the Zhao, Qu and Jing clans of Chu, descendants of the former royal families and the powerful clans of the Six States of former times, in the area within the Pass were moved to the area of the capital.

50 East of the pass or Guandong 關東 indicates the North China Plains.

51 Named the new capital Chang'an.

52 Jing 竟 is a variant for jing 境, see Jiyun, 6.20 ("Shang sheng. Sanshiba geng. Juying qie” 上聲·三十八梗·舉影切).

53 This refers to Lou Jing's plan of heqin marriage between the Han and Xiongnu to bring stability to the northern border territories. See Michael Loewe. A Biographical Dictionary of the Qin, Former Han and Xin Periods (221 BC-AD 24) (Leiden: Brill, 2000), 412-3.

54 Bo Yan is Bo Zhu 伯杼, legendary ruler of the Xia dynasty whose father was Shao Kang 少康. See Sarah Allan, "The myth of the Xia dynasty", The Journal of the Royal Asiatic Society of Great Britain and Ireland, 1984/2, 242-56.

$55 \mathrm{Fei}$ 罒 is a version of bi 彼, see Yupian 玉篇 (Taipei: National Central Library, 1982), 244 (“Fang bu” С部) (匪, 彼也).

56 The phrase kangkai 慷慨 is included in "Mourning Ying" (Ai Ying 哀郢) of the "Nine Cantos" (Jiuzhang 九章) in the Chuci buzhu, 8.304. Sukhu, The Songs of Chu, 113, refers to one who is impassioned and vehement.

$57 S h u$ 術 is a variant for shu 述, see Jinshi wenzi bianyi 金石文字辯異 (Taipei: Taipei Xinwen Feng Chuban, 1977), 10.23 (“Rusheng sizhi” 入聲四質).

58 The Huayang guo zhi, 3.217, mentions $\mathrm{Yu}$ the Great 大禹 being born in Wenchuan, located near Shiniu mountain 石纽山 in northern Sichuan province. The Shuijing zhu, 36.2961, also mentions Yu born at Shiniu (有石纽乡, 禹所生也). 
汶川之會.

幃屋甲悵, 59

龜車留遰. 60

家于梓湩, ${ }^{62}$

六族布列.

裳絻相襲，

名右冠盖.

君其始仕，

天資明哲.

典牧二城,

朱紫有别. and gathered [the Jing clan] at Wenchuan.

Tents [served as] dwelling [covered in the] finest canopy,

and in their "tortoise" carriages ${ }^{61}$ were halted and detained.

They made its family home at Zitong, ${ }^{63}$

and the six clans distributed and arranged [themselves

in the region]. ${ }^{64}$

In their garments and hats they each followed the pattern before,

[surpassing] the highest officials in their hats and carriages.

The gentleman [Jing Yun], from when he was first appointed to office,

had heaven-sent properties, was sagacious and wise. ${ }^{65}$

Shepherded two walled cities, 66

59 Chang 悵 is a variant for zhang 帳.

$60 D i$ 遰 is a variant for $z h i$ 滞.

61 Li Fang 李昉 (925-996 CE), Taiping yulan 太平御覽 (Shanghai: Shangwu yinshuguan, 1934), 677.297, quotes the Daoist canon of Shangqing taishang yuqing yinshu上清太上 玉清隱書 that mentions an eight-horse drawn "tortoise" carriage ridden by a Daoist immortal. For other suggestions on the meaning of the "tortoise" carriage see Sun Hua 孫華, “Handai Quren ling Jing Yun bei kaoshi buyi” 漢代朐忍令景雲碑考釋補遺, Zhongguo lishi wenwu, 2008.07, 52-3, where it is described as a carriage with a rounded cover used for transporting children and the elderly; Duan $\mathrm{Yu}$ 段渝, "Da Yu shichuan yu wenming de yanhua” 大禹史傳與文明的演化, Tianfu xinlun, 6, 2017, 132, where it is suggested that it refers to a special carriage that bears a flag with the image of an intertwined tortoise and snake, the symbol of protection; and Sukhu, The Songs of Chu, 30-1, where it is suggested that the image of the carriage or chariot is a symbol of the state in the Chuci.

62 Dong 湩 is a variant for tong 潼.

63 Zitong county is located in Mianyang 綿陽, Guanghan commandery.

64 This phrase suggests that the Jing clan became a powerful "magnate clan" in the region.

65 Wang Yi 王逸 in his poem titled "Meeting with reproach (Fengyou 逢尤)" in the "Nine longings" (Jiu si 九思) of the Chuci buzhu, 17.520, supports the view that the promotion of competent, loyal people is the only way to save the country. He wrote, "I think of Wu Ding and King Wen, who were saintly, sagacious and wise. I lament King Ping and Fuchai for their confusion, absurdity, and folly". See Timothy Wai Keung Chan, Considering the End: Mortality in Early Medieval Chinese Poetic Representation (Leiden and Boston: Brill, 2012), 33-4.

66 Walled cities in early China served as administrative centres. See Sen-Sen-You Chang, "The historical trend of Chinese urbanization", Annals of the Association of American Geographers, 53/2, 1963, 109, where the author mentions how walled cities became central places for rural areas and, as such, centres of Chinese settlement in regions previously populated by non-Chinese pastoral or agricultural peoples who did not normally build cities. They were also created as a result of increasing trade and exchange between other regional centres. He further notes (p. 119) that during Han times, people came in very large numbers into the Sichuan basin and many new walled cities were established in the Chengdu Plain.

67 This phrase suggests that he understood clearly the difference between right and wrong. Zhuzi 朱紫 appears in the poem titled “To blame" (Yuan shang 怨上) in the "Nine longings" (Jiusi 九思) of the Chuci buzhu, 17.522, where the ruler is blamed for not being 


彊68 不凌弱,
威不猛害.
政化如神,
丞民刀厲.
州郡 涉 ${ }^{71}$ 表,
當亨苻艾73.
大命顛覆,
中年徂殁. 76
如喪考妣,
載泣怛.
遏勾八音,
百姓流淚.
魂靈既載,

The strong were not to mistreat the weak, ${ }^{69}$ nor the authoritarian be severe and abusive. His government was transformative like a wondrous being, 70

and multitudes were thereupon inspired.

Prefecture and commandery [officials] jointly sent memorials, 72

and it was fitting that he should receive the tally and the cord. ${ }^{74}$

Yet his great mandate was suddenly reversed, ${ }^{75}$ and in his prime years he reached his death.

It was as if mourning for parents, ${ }^{77}$
All music was held back, ${ }^{78}$

and commoners let their tears flow.

While his spirit was still present, ${ }^{79}$

able to recognize the worthy and selects those who wear purple and abandons those who wear vermilion (朱紫兮雜亂,曾莫兮别諸). The purple and vermilion is an allusion to Confucius (551-479 BCE) who had esteemed vermilion because it was an unadulterated royal colour. See Brashier, Public Memory in Early China, 1.

68 Jiang 彊 is a variant for qiang 強, see Libian 隸辨, $2.42 \mathrm{https}$ ://archive.org/details/ 06070861.cn, last accessed 16 March 2019.

69 The phrase “qiang bu ling ruo" 強不凌弱 is taken from Guanzi jiaoshi 管子校釋 (Changsha: Yuelu shu she, 1996), 67.59 ("Ming fa jie” 明法解).

70 Suggesting that his governance and administration was well ordered and just.

71 Bing 竝 is a variant for bing 並. See Shuowen jiezi 說文解字 (Beijing: Zhonghua shuji, 1963), 10B.216.

72 Suggesting that memorials were sent to the throne in praise of Jing Yun's conduct and achievements.

73 Heng 亨 is a variant for xiang 享, see Libian, 3.68; $f u$ 苻 is a variant for $f u$ 符, see Shuowen jiezi, 5A.96; and chai 艾 is a variant for yi 艾, see Shuowen jiezi, 1B.19.

74 Silver seals with green cord attached to it were given with tallies, suggesting that Jing Yun held an official position of or above the rank of 2,000 shi.

75 The phrase dianfu 顛覆 is in the poem by Liu Xiang 劉向 titled "Encountering troubles" (Fengfen 逢紛) in the “Nine laments" (Jiutan 九歎) of the Chuci buzhu, 16.466, referring to a destructive event.

$76 M o$ 殁 is a variant for $c u$ 殂.

77 This phrase and the next two lines are after the Shangshu 尚書 in Shisanjing suoyin十三 經索引, vol. 1 (Beijing: Zhongguo shehui kexue chubanshe, 2003), 2.125 ("Shundian" 舜典) (百姓如喪考妣, 三載, 四海遏密八音). The phrase is also included in the Mengzi 孟子 in Shisanjing suoyin 十三經索引, vol. 1 (Beijing: Zhongguo shehui kexue chubanshe, 2003), 29.2735 ("Wang zhang shang" 萬章上), which translates as, “The people acted as if they were mourning for a parent for three years, and to the borders of the four seas all sound of music was hushed” (百姓如喪考妣, 三年, 四海遏密八音).

78 This refers to the eight different types of musical instruments used at ceremonies, suggesting that he was appropriately buried and all necessary rituals were completed. The eight musical instruments, listed in the Zhouli 周禮 in Shisanjing suoyin 十三經索引, vol. 4 (Beijing: Zhongguo shehui kexue chubanshe, 2003), 35.795 ("Chunguan zongbo" 春官宗伯), were made of metal ( $j i n$ 金), stone (shi 石), earth ( $t u$ 土), leather ( $g e$ 革), silk ( $s i$ 絲), wood ( $m u$ 木), gourd (pao 匏) and bamboo ( $z h u$ 竹).

79 Suggesting that he was not buried yet. With his body still present, his spirit was able to benefit from cries, speeches, gifts, and songs. 
農夫惻結;

行路撫涕,

織婦喑咽.

吏民懷慕,

户有祠祭;

烟火相望,

四時不絕.

深墅曠澤,

哀聲切切。

追歌遺風，

嘆續億世.

刻石纪號，

永永不滅。

鳴呼哀哉,

鳴呼哀哉!

讚曰:

皇靈炳璧,

虽令名矣.

作民父母,

化洽平矣.

百工维時,

品流刑 88 矣. farmers were afflicted,

travellers on the road brushed away their tears,

weaving women sobbed in silence, ${ }^{80}$

and officials and commoners longingly grieved.

When households presented their offerings and sacrifices,

they could see each other's smoke and fire in the distance ${ }^{81}$

that did not stop throughout the four seasons. ${ }^{82}$

Even in the deep wilderness and vast marshlands

there were sounds of mourning distressingly pressing. ${ }^{83}$

They sang about his air and manners,

sighed lasting for a hundred thousand generations. ${ }^{84}$

Inscribed this stone to record his name,

so that it would last forever and never be obliterated.

Oh, alas!

Oh, alas!

We praise saying:

His ancestors [shine] luminously [piercing through] the $b i$ [to Heaven], ${ }^{85}$

[established their] excellence and name in Ying. ${ }^{86}$

He acted as father and mother to people,

and transformed [society to be] content and peaceful.

The hundred kinds of artisans adhered to the season ${ }^{87}$

80 Indicating that they did not talk or tell stories as was the custom while weaving. The Hanshu, 24.1121, records how in the winter people stayed indoors and women who dwelled in the same alleyway did their spinning together at night.

81 Seeing smoke and fire suggests that offering incense is burnt continuously for Jing Yun.

82 This suggests that sacrifices were presented every season without exception.

83 Suggesting being deep in the wilds and far away. It may be a reference to the isolated geographical location of the south-west and its great distance from the seat of the government.

84 Yifeng 遺風 is mentioned in relation to the state of Chu in the Huainan hongjie jijie 淮南 鴻烈集解 (Beijing: Zhonghua shuju, 1989), 1.75 ("Yuan dao" 原道), “getting wrapped up in the stirring traditional ballads of Chu” (結激楚之遺風). Sukhu, The Songs of Chu, 112 , translates this phrase as "missing the ancient river-land ways", referring to the landscape of Chu. In the context of the stele, it suggests the invisible influence of Jing Yun's leadership that continues to affect society for years to come and thereby justifies public mourning and seasonal sacrifices.

85 The phrase “huangling jianzhong” 皇靈建中 is included in the Jiaoshi yilin, 37.176 (“Jia ren zhi” 家人之). The character huang 皇 also refers to ancestors or deceased parents. The phrase "piercing through the $b i$ to Heaven" refers to the ritual practice of placing jade $b i$ discs on the deceased's body that was believed to guide the soul of the dead into heaven through the hole in the centre of the disc.

86 Ying was the capital of the state of Chu. This phrase reminds the viewer that the Jing clan was from the state of Chu.

87 This phrase may be after the Huainan hongjie jijie, 20.1406 (“Taizu xun” 泰族訓), (百工維時, 庶績鹹熙, 禮義修而任賢德也).

88 Xing 刑 is a variant for xing 形. See Libian, 2.58.

89 The phrase is included in the Zhouyi 周易 in Shisanjing suoyin 十三經索引, vol. 1 (Beijing: Zhongguo shehui kexue chubanshe, 2003), 1.14 ("Qian” 乾), "goods of quality appear in their developed forms" (品物流形). 
善勸惡懼,

物咸寧矣. ${ }^{90}$

三考絀 ${ }^{91}$ 勅, ${ }^{92}$

陟幽名93 矣.

振華處實,

畼96 遐聲矣.

重曰:

皇靈禀氣,

卓有純兮.

惟汶降神, 梃99 斯君兮.

未升卿尹,

中失年兮.

流名后載,

久而榮兮.

勒銘金石,

表續勳兮.

冀勉来嗣,

示後昆兮.
The good were encouraged and the bad were afraid, and all things were harmonious and pacified.

Every three [years there is an] inspection of merit by imperial order,

[by means of which] the undeserving are degraded and the deserving advanced. ${ }^{94}$

[Jing Yun] marshalled the illustrious and implemented honesty, ${ }^{95}$

[thus his reputation] was heard unimpeded in distant [lands].

We re-praise saying: 97

[Jing Yun's] ancestors have received [Heaven's natural] $q i$

that is splendid and pure.

Only from Wenchuan can such spirit descend, ${ }^{98}$

the gentleman stands upright ah!

[Jing Yun] had not yet been promoted to [the rank of] the highest governor,

when in his prime years he passed away.

His name spreads in later generations,

and he is honoured for a long time.

[Thus this stele has been] engraved on metal and stone,

to continue [serving] as a model for merit.

Hoping to encourage future generations,

and to inform posterity.

喜平二年仲春上旬朐忍令梓湩 100 雍君諱陟字伯曼为景君刊斯铭兮.

90 The Qian Han ji 前漢記 in Sibu congkan 四部叢刊 (Shanghai: Shangwu yinshuguan, 1929), 10.7, mentions the phrase "all things are harmonious and peaceful" (萬物咸寧).

$91 C h u$ 絀 is a variant for $j i$ 績.

$92 C h i$ 勅 is a variant for chi 敕. See Jiyun, 10.18 (“Rusheng. Ershisi zhi. Xuli qie” 入聲. 二十四職・蓄力切).

93 Ming 名 is a variant for ming 明.

94 This phrase may be after the Shangshu, 2.132 ("Shundian" 舜典), “Every three years there was an examination of merits, and after three examinations the undeserving were degraded, and the deserving advanced” (三載考績, 三考, 黜陟幽明). An allusion to the sage ruler Shun 舜 who had exemplified good government.

95 This phrase may be after Wang Jipei 汪繼培 (1751-1819), Qianfu lun jian 潛夫論箋 (Beijing: Zhonghua shuju, 1979), 29.328 (“Shinan” 釋難), where it notes how men of greatness dwell with the fruit and not with the flower (處其實, 不居其華), meaning that they choose sincerity and honesty over empty magnificence and that they are more concerned with the end result, i.e. the fruit rather than the process, i.e. the flowering stage.

96 Chang 畼 is a variant for chang 暢.

97 The use of "re-praising" is unusual in stele inscriptions. We find it in the "Yuanyou" of the Chuci buzhu, 5.274.

98 See the Shijing 詩經, in Shisanjing suoyin 十三經索引, vol. 1 (Beijing: Zhongguo shehui kexue chubanshe, 2003), 52.565 ("Daya" 大雅) for the phrase "from these mountains was sent down a spirit” (維获降神).

99 Ting 梃 is a variant for ting 挺. See Jinshi wenzi bianyi, 6.42 ("Shangsheng. jiongyun" 上聲・迥韻).

100 Dong 湩 is a variant of tong 潼. 
This stele was carved for gentleman Jing by the Quren county magistrate, gentleman Yong from Zitong, whose now-tabooed personal name is Zhi, and his courtesy name is Baiman, in the beginning of the second month of Spring, in the second year of the Xiling reign $(173 \mathrm{CE}) .{ }^{101}$

\section{Commentary on the text}

The text on the stele may be divided into three parts: a preface (lines 1-22), a biography of Jing Yun in the form of an extended eulogy (lines 23-54); and a post-script (lines 55-80) which consists of two distinct sections (lines 55-67 and $68-80$ ). The preface provides a precise placing of the dedicatee, a technique used in stelae inscriptions to position the person in local memorial culture. ${ }^{102}$ In giving an account of Jing Yun's ancestors, the third line of the text directly borrows from the poem “On encountering sorrow" (Lisao 離騷) (“Lisao" hereafter), from the Chuci, quoting "descendant of Emperor Gaoyang the God Lord" (帝高陽之苗裔). ${ }^{103}$ These opening lines stress the clan's imperial southern heritage and record their eminent status within the state of Chu prior to the establishment of the Han dynasty.

During the reign of Emperor Gaozu (r. 202-195 BCE), the clan moved away from their homeland of Chu and settled down in Guanghan commandery, making their family home in Zitong, located in present-day Sichuan province (lines 8-12). There is no specific mention of the reasons behind the clan's relocation, except for the region being described as the birthplace of $\mathrm{Yu}$ the Great and as such a location deemed worthy of settlement (lines 13-18). However, the text mentions Lou Jing, political advisor to Gaozu and initiator of policies that were subsequently implemented by the Han government (lines 8-12). Lou's political, social, and military strategies, as the text notes, made a significant contribution to the stability of the empire (line 12). Lou recommended moving the powerful magnate clans ( haozu 豪族) to the metropolitan area, known as the Guanzhong 關中 region, so that the government could keep them under surveillance and control. This reference to Lou on the stele serves as an explanation for the transfer of the Jing clan from Chu. ${ }^{104}$ It accords with the recordings of the

101 Yong Zhi is recorded in the Hou Hanshu, 86.2847, as governor of Yizhou commandery 益州郡. In $176 \mathrm{CE}$, Yong Zhi was captured by ethnic rebels who came to control Yizhou. Some officials suggested that the Eastern Han give up Yizhou, since the Han court was unable to suppress the rebels. It was only with the help of the Bandun ethnic "barbarians" from the Ba region that the Han military managed to suppress rebellion and temporarily end the conflict between the Han and the ethnic tribes in the south-west. This military conflict destroyed the local economy and population, and the indigenous elites had no resources with which to turn against the Han court, while the new Han officials launched a relaxation policy. The Huayang guo zhi, 2.91, mentions the four clans of Wen 文, Jing 景, Yong 雍 and Deng 鄧 as the four major haozu in Zitong county 梓湩縣 in Guanghan commandery.

102 See Brashier, Public Memory in Early China, 267, where the author notes how name, age and kinship became tools for giving presence to the deceased.

103 Chuci buzhu, 1.10 (離騷經者屈原之所作也) and 1.12.

104 For the biography of Lou Jin see Loewe, A Biographical Dictionary, 412-3. 
Hanshu which lists the Jings amongst the five major clans from the state of $\mathrm{Chu}$ who were transferred during the reign of Gaozu. ${ }^{105}$ The clan's prominence in the south-west continued as they benefitted from an eminent status in society (lines 21-22), retaining their customary dress code and enjoying the same elevated position as the local officials of rank and status. Asserting Shiniu in the southwest as Yu's birthplace also claims a weighty role for the region. More than twenty sites throughout China are mentioned as the birthplace of $\mathrm{Yu}$ in classical literature and reference to it became a trope to indicate an elevated status for a locality. ${ }^{106}$

Reference to Lou Jing in the text also suggests that his policies had a significance for the stele's dedicator, Yong Zhi. ${ }^{107}$ The Hou Hanshu mentions the promotion of Yong Zhi to the governorship of Yizhou commandery sometime between 173 and 176 CE. ${ }^{108}$ We know of his position as Quren county magistrate, prior to taking up the position of governorship, only from the stele. This period in the south-west's history, especially the region of Yizhou commandery (located in present-day Yunnnan province), was characterized by continuous unrest amongst the ethnic population who rebelled in large numbers against the Han military forces. ${ }^{109}$ Yong Zhi was captured in $176 \mathrm{CE}$ when Yizhou fell into the hands of the rebels. The Han government was only able to regain control of the region and save him from the rebel forces when they allied with the Bandun 板楯 ethnic people from Ba commandery and introduced a more relaxed and compassionate policy towards the region's population. ${ }^{110}$ Although not yet posted to Yizhou at the time of erecting the stele in $173 \mathrm{CE}$, Yong Zhi may have been already aware of the counterproductive nature of the Han Empire's confrontational occupation of the border territories and the futility of endless warfare. Drawing attention to Lou's pacifying policies towards the Xiongnu over three centuries earlier may have served as an example and model for bringing peace and stability to the south-west and avoiding further military conflict. ${ }^{111}$ With the erection of the stele he may have wished to emphasize lessons learnt from past events for the sake of current and future policies.

Following the preface, the text elaborates on Jing Yun's deity-like qualities and how he became an inspiration to the people and officials in the region (lines 24-28). Regrettably, he met with an untimely death in his prime that prevented him from enjoying recognition and the promotion he deserved (lines 31-34). A further parallel with the "Lisao" may be drawn here. The "Lisao" focuses on the sociopolitical aspects of human life and describes the existence of a pure and devoted official

105 Hanshu, 1B.66.

106 Meng Mo 蒙默, “Yu sheng Shiniu xubian” 禹生石紐續讋, Xihua daxue xuebao, 2010.4, 1-6.

107 Both the Shiji and the Hanshu provide detailed accounts on Lou Jing and his policies. See Shiji, 99.2715 and Hanshu, 43.2119; 30.1726; 64A.2801; and 87B.3572.

108 Hou Hanshu, 86.2847.

109 Bin Yang, Between Winds and Clouds (New York: Columbia University Press, 2009), 106.

110 Hou Hanshu, 86.2847. See also Bin, Between Winds and Clouds, 106-7.

111 After many years of warfare, Lou Jing was dispatched in 198 BCE to negotiate a peace settlement with the Xiongnu and implement his proposed marriage alliance between the Han princess and the Xiongnu chieftain. See Loewe, A Biographical Dictionary, 412-3. 
amidst a world of injustice where his lofty aspirations remain unfulfilled. It also articulates an honest official's inner conflict, the contradiction between the urge to escape into a pure and ideal realm on the one hand and a deeply engrained feeling of moral responsibility to work for the good in the human world on the other. ${ }^{12}$ Jing Yun may be seen as the pure and devoted official who, although prevented from reaching the path of success he deserved, was able to achieve a state of transcendence and became a local cult figure with deity-like qualities. Yong Zhi may have considered Jing Yun as a model, seeing himself also as a dutiful official with a governance responsibility but not able to pursue his personal ambitions and spiritual fulfilment in the world surrounding him. The themes of lament in the text and the depiction of spiritual journey in the relief carving on the head of the stele were relevant to Jing Yun's life but also to Yong Zhi himself.

The opening lines of the "Yuanyou" may give us a further insight into Yong Zhi's predicament. It reads, "Grieving at a dead end in a degenerate time, I wished to be weightless, to ascend and wander far away, But with no such power among my feeble gifts, What would I ride to float to the sky?" (悲時 俗之近阨兮，願輕舉而遠遊. 質菲薄而無因兮，焉託乘而上浮?). ${ }^{113}$ Gopal Sukhu in his analysis of this passage suggests that it provides an image where the spirit of the main persona wanders through another dimension, the spirit world that, in the modern view, could be seen as a combination of internal and external reality. ${ }^{114}$ Perhaps Yong Zhi wished to become xian-like in the footsteps of his predecessor, Jing Yun, who continued to live in public memory 70 years after his death. Yong Zhi's predicament is reflected in the juxtaposition of two worlds, the world of the xian and that of men as expressed in the stele.

Jing Yun's memorialization as a god-like figure should also be understood in the context of the Chu culture as described by Wang Yi in his commentary:

昔楚國南郢之邑，沅湘之間，其俗信鬼而好祠．其祠必作歌樂鼓舞以樂 諸神。屈原放逐竄伏其域，懷憂苦毒愁思沸缽。出見俗人祭祀之禮歌舞 之樂。

In the old days the people of Chu who lived in the area around the old southern capital and the lands lying between the rivers Yuan and Xiang, were a superstitious folk much addicted to a kind of religious rite in which they entertained various gods with singing, drumming and dancing. After his banishment, when $\mathrm{Qu}$ Yuan was living in hiding in this area, he would sometimes emerge to seek distraction from the burden of grief and care which oppressed him by observing the villagers at these rustic festivals, singing and dancing to delight the gods. ${ }^{115}$

Sukhu, in his examination of the Chuci and images of Chu during the Eastern Han period, notes how Chu culture, with its preoccupation with the worlds of the shamans and spirits, came to be criticized by the old Confucian literati the group with which the Han Reformists most closely identified and who

112 Kirkova, Roaming into the Beyond, 262-3. For a study of the "Lisao" see Sukhu, The Shaman and the Heresiarch.

113 Chuci buzhu, 5. 269-70; tr. Sukhu, The Songs of Chu, 143.

114 Sukhu, The Songs of Chu, 142-3.

115 Chuci buzhu, 2.98; tr. Hawkes, The Songs of the South, 96. 
took a strongly anti-Chu and anti-shamanistic stand in their political ideals. ${ }^{116}$ The so-called "Chu mode", reflected in the Chuci, thus came to be associated with a culture perceived to be barbarian that had no place amongst the literary circles of the Eastern Han court, yet as we see from Jing Yun's stele, not only survived, but was preserved in the literature and political rhetoric of the south-west.

Regarding the south-west's economy, the text mentions how Jing Yun ensured that the "hundred kinds of artisans adhered to the season and goods flowed in their proper shapes" (lines 60-61). Considering that he was in charge of two walled cities (line 25) and the general prosperity of the county, mentioned earlier, we can assume that the success of his governance fostered the manufacture of quality goods. Apart from the south-west's economic wealth we are also given an insight into how officials were advanced or degraded following an inspection of merit every three years (lines 64-65) and the extent of power held by county officials, such as Jing Yun, who appear to have had considerable influence in these matters (line 66). The final section of the text reiterates the reasons for the erection of the stele, reminding us how Jing Yun's name and achievements might serve as a model and are transmitted and preserved for the future (lines 77-80).

\section{Text and its relation to the $\mathrm{Chuci}$}

We have already seen connections with the Chuci in the pictorial images of the xian, Vermilion Bird, and the half open-door. There is a further parallel between the narrator of the "Yuanyou" as a wearied official longing for spiritual transcendence and the stele's text. Further links with the Chuci, in particular the "Yuanyou", can be found when we examine the language and structure of the text. The purpose of this paper is not to provide commentary on the the "Yuanyou" itself, which is already much discussed, but to highlight its influence on the text of the stele. Paul Kroll notes how the "Yuanyou" is constructed from a series of vignettes and shifts in topic or action that divide the long composition into sections and notes how sometimes these sections correspond with changes in rhyme. ${ }^{117}$ The same technique is employed in the post-script of the stele which is divided into two distinct sections that are differentiated by changes in rhyme. The first section (lines 55-67) employs the sentential marker yi 矣, with every word before $y i$ rhyming with ming 名 in the first couplet. Due to phonetic changes in the Chinese language over time it is not always easy to hear these rhymes, thus they are clarified in Table 1.

The second section (lines 68 to 80 ) employs the rhythmic particle and pause marker $x i$ 兮 with the words before $x i$ rhyming in every pair of couplets, as shown in Table $2 .{ }^{118}$

116 Gopal Sukhu, "Monkeys, shamans, emperors, and poets: the Chuci and images of Chu during the Han dynasty", in Constance A. Cook and John S. Major (eds), Defining Chu (Honolulu: Hawaii University Press, 2004), 157. See also Michael Loewe, Crisis and Conflict in Han China (London: George Allen and Unwin, 1974), preface, for an explanation of the reformist camp in the Han court.

117 Kroll, "On 'Far roaming", 655.

118 For the reconstruction of pronunciations in Middle and Old Chinese see the table "Baxter-Sagart Old Chinese Reconstruction, version 1.1 (20 September 2014)" by 
Table 1. Pronunciation of rhyming characters before the marker yi in Standard Pinyin, Middle Chinese, and Old Chinese

\begin{tabular}{|c|c|c|c|}
\hline & Standard Pinyin & Middle Chinese & Old Chinese \\
\hline $\begin{array}{l}\text { 讚曰: 皇靈炳璧, 郢令名矣. } \\
\text { 作民父母, }\end{array}$ & míng & mjieng & *C.men \\
\hline $\begin{array}{l}\text { 化洽平矣. } \\
\text { 百工维時, }\end{array}$ & píng & bjaeng & *m-bren \\
\hline $\begin{array}{l}\text { 品流刑矣. } \\
\text { 善勸惡懼, }\end{array}$ & xíng & heng & $*[\mathrm{G}]$ Sen \\
\hline $\begin{array}{l}\text { 物咸寧矣. } \\
\text { 三考絀勅, }\end{array}$ & níng & neng & $*_{n}$ Sen \\
\hline $\begin{array}{l}\text { 陟幽名矣. } \\
\text { 振華處實, }\end{array}$ & míng & mjaeng & *mray \\
\hline 畼遐聲矣. & shēng & syeng & $*[1]$ en \\
\hline
\end{tabular}

Table 2. Pronunciation of rhyming characters before the marker $x i$ in Standard Pinyin, Middle Chinese, and Old Chinese

\begin{tabular}{|c|c|c|c|}
\hline & Standard Pinyin & Middle Chinese & Old Chinese \\
\hline \multicolumn{4}{|l|}{ 重曰: 皇靈禀氣, } \\
\hline 卓有純兮。 & chún & dzywin & $*[\mathrm{~d}] \mathrm{u}[\mathrm{n}]$ \\
\hline 梃斯君兮. & jūn & kiun & *C aur \\
\hline \multicolumn{4}{|l|}{ 未升卿尹。 } \\
\hline \multicolumn{4}{|l|}{ 流名后載, } \\
\hline 久而榮兮野。 & róng & hiwaeng & $*[\mathrm{~N}$-qw]ren \\
\hline \multicolumn{4}{|l|}{ 勒銘金石， } \\
\hline 表續勳兮. & xūn & xjwon & *qho[n] \\
\hline \multicolumn{4}{|l|}{ 冀勉来嗣, } \\
\hline 小後昆合. & kūn & kwon & $*[\mathrm{k}] \mathrm{Su}[\mathrm{n}]$ \\
\hline
\end{tabular}

The use of rhyme and markers, such as $y i$ and $x i$, in the text highlights the climax of the lament and suggests a familiarity with the rhyming mode of the Chuci. The function of $x i$ in the Chuci was meant to be musical. This technique displays a familiarity with the rhyming mode of the Chuci that regularly employs markers such as the $x i$, which is placed at the end of each line with the rhyme taking place in the last word before it. The function of $x i$ in the Chuci was meant to be musical, since it does not have a meaning except as an indication of emphasis as a drawn out sound of a sigh or an "ah" in modern Chinese. ${ }^{119}$ The inclusion of poetic rhyming in the stele's text suggests that these passages may have been

William Baxter and Laurent Sagart, http://ocbaxtersagart.lsait.lsa.umich.edu/ BaxterSagartOCbyMandarinMC2014-09-20.pdf, last accessed 1 April 2019.

119 Cai Zong-qi, How to Read Chinese Poetry. A Guided Anthology (New York: Columbia University Press), 37. 
chanted when read. As mentioned earlier, shamanistic chants and invocations supplied much of the stimulus for the songs of the Chuci. Kroll notes how the placement of musical interludes in the "Yuanyou" may have been intended to produce a sense of euphoria equivalent to the rapt trance of the shaman and allowed the poet to break free of all bounds. ${ }^{120}$

The language of mourning in the text is also reiterated with the use of the phrase "we re-praise saying" (zhongyue 重曰), that creates an additional unit following the customary eulogy presented by the phrase "we praise saying" (zanyue 讚曰). The two sections of the post-script, analysed above, are introduced into the text with the phrases zangyue and zhongyue respectively. The "Yuanyou" utilizes zhongyue as a formal link to an additional section in the poem which repeats the poet's lament for aspirations beyond his reach. ${ }^{121}$ The adoption of recursive forms that reiterate or turn back upon themselves, suggesting a conscious reflection on an emotion, is examined by Douglas Hofstadter who suggests that recursions help induce a mental state in which the mind has the ability to move up to a higher level of comprehension. ${ }^{122}$ Hofstadter finds examples of this approach in music and in literary works, thus it is not surprising that we see the same in the poetic craft of the "Yuanyou" and similarly in Jing Yun's stele. As we can see, the text in Jing Yun's stele employs two distinct poetic techniques from the Chuci, in particular from the "Yuanyou", that confirm a familiarity with the anthology. The use of rhyming schemes of this kind are exceptional on stelae.

\section{Conclusion}

Amongst Eastern Han commemorative stelae from the south-west, Jing Yun's monument stands out for its carved decoration, calligraphy, and for the content of its inscription. It represents important documentary and material evidence for the study of local and regional history. Furthermore, it appears to incorporate literary and cultural references from the southern anthology, the Chuci. There is an emphasis on the heritage of the state of $\mathrm{Chu}$ and its culture in the description of the ancestry of the Jing clan and in the language of praise for Jing Yun who became a god-like figure in society. Studies on the Chu culture note the importance of deity worship and how people made extensive use of sacrificial rites of singing and dancing which distinguished it from other cultures, especially those of north China and the Central Plains. ${ }^{123}$

Alongside the eulogy and accounts of mourning, there are specific references to society, the economy and governorship. These narrations, which were created for specific local purposes, reflect society's wish to record events or certain individuals for the preservation of memories that are continually shaped to fit the

120 Kroll, "On 'Far roaming", 658.

121 See the poem "Yuanyou" in the Chuci buzhu, 5.269-88.

122 Douglas R. Hofstadter, I Am a Strange Loop (New York: Basic Books, 2007), 102; Nicholas Morrow Williams, "Tropes of entanglement and strange loops in the "Nine avowals' of the Chuci", Bulletin of SOAS 81/2, 2018, 278-9.

123 Lang Ye et al. (eds), China: Five Thousand Years of History and Civilisation (Hong Kong: City University of Hong Kong Press, 2007), 204. 
needs and circumstances of the moment. ${ }^{124}$ While we can only speculate on the intentions behind the erection of the stele, it is likely, given the tumultuous conditions of the south-west in the Han empire at this time, that the text's deliberation on the past was included because it was seen as relevant to the contemporary context of the challenge in governing a border territory at a time of political and military unrest.

The pictorial imagery on the head of the stele provides a further clue to the dedicator's possible objectives. The carved decoration and the text below it represent two distinct spheres - the former the mythical terrain of the xian immortals, the latter the ephemeral and transient nature of life lived and mourned after death. The tension between the two spheres is captured in the persona of the narrator of the "Yuanyou", who laments his burden of official duties and longs for spiritual journeying. This poem may well also have inspired the stele, imbued as it is with quotations from and imitations of the poem's literary style, as well as containing images which also relate closely to it.

The stele also gives us an insight into a number of events that are informative and remain worthy of our examination. For example, we read about the nature of the relocation of notable clans from the former state of $\mathrm{Chu}$, their settling in the south-west territories and the prominence of the memory of this heritage many centuries after the settlement; the training and selection of local officials; the importance of artisans and the production of goods to the region's economy; and in general, the process of how officials were memorialized by colleagues in early China.

The stele reveals the influence of the cultural heritage of the Jing clan in the south-west and of how the language, vocabulary and rhyming system of the Chuci was preserved, transferred and used in its intellectual milieu. In the text we glimpse a society that celebrates an identity that is linked to the state and the culture of Chu, not only because of the Jing family's line of ancestry but also because that identity is lived in both the imagination and in texts. Poems such as the "Yuanyou" became a source of inspiration for its poetic idioms but perhaps, more importantly, for the themes of lament and its voicing of anguish with the transience and limitations of one's existence, all of which are expressed in the stele's text and images. The examination and interpretation of stelae remains a neglected field, possibly due to the challenges of deciphering their complex language and content; nevertheless, close study of these artefacts and their texts shows a depth of meaning and reveals their significance to our understanding of the period. 